\title{
Review on Newcastle Disease of Poultry and its Public Health Importance
}

\author{
Tagesu Abdisa* and Tolera Tagesu*
}

Jimma University College of Agriculture and Veterinary Medicine, Jimma, Ethiopia

\begin{abstract}
Newcastle disease is a contagious bird disease affecting many domestic and wild avian species and which can be transmissible to humans. It is caused by avian paramyxovirus serotype 1 virus which, with viruses of the other eight serotypes (avian paramyxovirus 1-9) has been placed in the genus Avulavirus, sub-family Paramyxovirinae, family Paramyxoviridae. Virulent Newcastle disease virus strains are endemic in poultry in most of Asia, Africa, and some countries of North and South America. Other countries, including the united states of America and Canada, are free of those strains in poultry. Highest prevalence of Newcastle disease is recorded in cross breeds of chickens than local breed and the low altitudes do have higher prevalence than the mid and high altitudes. The transmission of Newcastle disease occurs through respiratory aerosols, exposure to fecal and other excretions from infected birds, through newly introduced birds, selling and giving away sick birds and contacts with contaminated feed, water, equipment and clothing. The strain of Newcastle pathogenicity can be classified into five pathotype: Asymptomatic enteric strain; Lentogenic strain; Mesogenic stain; Viscerotropic velogenic strain and Neurotropic velogenic strain. Clinical signs are extremely variable depending on the strain of virus, species and age of bird, concurrent disease, and preexisting immunity caused by paramixovirus with worldwide distribution affecting chickens (all poultry and birds are susceptible) of All age group are susceptible. Symptoms from the respiratory tract are gasping, coughing, sneezing and rales. Signs from the nervous system include tremors, paralyzed wings and legs, twisted necks, circling, clonic spasms and sometimes complete paralysis. Other general symptoms that can be seen are greenish diarrhea, depression and inappetence, partial or complete drop in egg production and an increased production of deformed eggs. Clinical diagnosis based on history, signs and lesions may establish a strong index of suspicion but the laboratory confirmation must be done. The general approaches to the control of Newcastle disease are hygiene and vaccination. Humans are among the many species that can be infected by Newcastle disease in addition to avian species. Newcastle disease may cause conjunctivitis in humans, when a person has been exposed to large quantities of the virus. Mostly, Laboratory workers and vaccinators are affected. Recently, the disease which decreases the development of poultry production for industry is the infectious diseases, among infection disease Newcastle is the one which causes economical lose of poultry and its product. The objective of this review is to understand the Newcastle disease causative agent, pathogenicity, clinical sign and how to prevent and control the Newcastle disease, which concerned with the currently published or reported research.
\end{abstract}

Keywords: Newcastle disease; Pathogenicity; Avulavirus; Poultry; Vaccination

\begin{abstract}
Abbreviations: PMV: Avian Paramyxovirus; $\mathrm{C}$ terminus: Cleavage terminus; ELISA: Enzyme Linked Immune Sorbent Assay; END: Exotic Newcastle Disease; HA: Hemagglutinin; HN: Hemagglutinin Neuraminidase; HPAI: Highly Pathogenic Avian Influenza; loNDV: Low virulence Newcastle disease virus; M: Matrix; mRNA: Messenger Ribonucleic Acid; NP: Nucleoprotein; NDV: Newcastle disease Virus; NVND: Neurotropic velogenic Newcastle disease; P: Phospho Protein; PCR: Polymerase Chain Reaction; RBC: Red Bood Cell; RT-PCR: Reverse- transcriptase polymerase chain reaction; vNDV: Virulent Newcastle Disease.
\end{abstract}

\section{Introduction}

Poultry, the largest livestock group, account for more than $30 \%$ of all animal protein. However, this production is mainly based on commercial poultry, which accounts for only $20 \%$ of the total poultry population [1]. Based on the number of animals, poultry represents the largest domestic animal stock in the world [2]. Poultry represents an important sector in animal production, with backyard flocks representing a huge majority, especially in the developing countries. In these countries, villagers raise poultry to meet household food demands and as additional sources of incomes. Backyard production methods imply low biosecurity measures and high risk of infectious diseases, such as Newcastle disease or zoonosis such as HPAI [3]. Newcastle disease is a contagious bird disease affecting many domestic and wild avian species; it is transmissible to humans [4]. Newcastle disease is an important infectious disease of the poultry that is caused by virulent strains of Avian Paramyxovirus -1, which is a single strand nonsegmented negative sense RNA virus (Figure 1) [5].

The epizootics of Newcastle Disease in poultry continue to occur in Asia, Africa, Central and South America while in Europe, sporadic epizootics occur [6]. In developing countries, human diet is deficient in the animal proteins; approximately $66 \%$ population has protein deficient diet [7]. Newcastle disease is an economically important disease and also a major threat to poultry industry [8]. According to variation in strains of NDV, the rate of mortality and morbidity in a flock is variable [9]. Pathotyping of Newcastle disease viruses by RT-PCR and restriction enzyme analysis along with decrease in egg production [10]. Isolation of

*Corresponding authors: Tagesu Abdisa, Jimma University College of Agriculture and Veterinary Medicine, Jimma, Ethiopia, Tel: +251933681407; E-mail: abdisatagesu@gmail.com

Tolera Tagesu, Jimma University College of Agriculture and Veterinary Medicine, Jimma, Ethiopia, Tel: +251917590810; E-mail: toleratagesu3@gmail.com

Received April 19, 2017; Accepted May 05, 2017; Published May 06, 2017

Citation: Abdisa T, Tagesu T (2017) Review on Newcastle Disease of Poultry and its Public Health Importance. J Vet Sci Technol 8: 441. doi: 10.4172/21577579.1000441

Copyright: ( 2017 Abdisa T, et al. This is an open-access article distributed under the terms of the Creative Commons Attribution License, which permits unrestricted use, distribution, and reproduction in any medium, provided the original author and source are credited. 
Citation: Abdisa T, Tagesu T (2017) Review on Newcastle Disease of Poultry and its Public Health Importance. J Vet Sci Technol 8: 441. doi: $10.4172 / 2157-7579.1000441$

A.

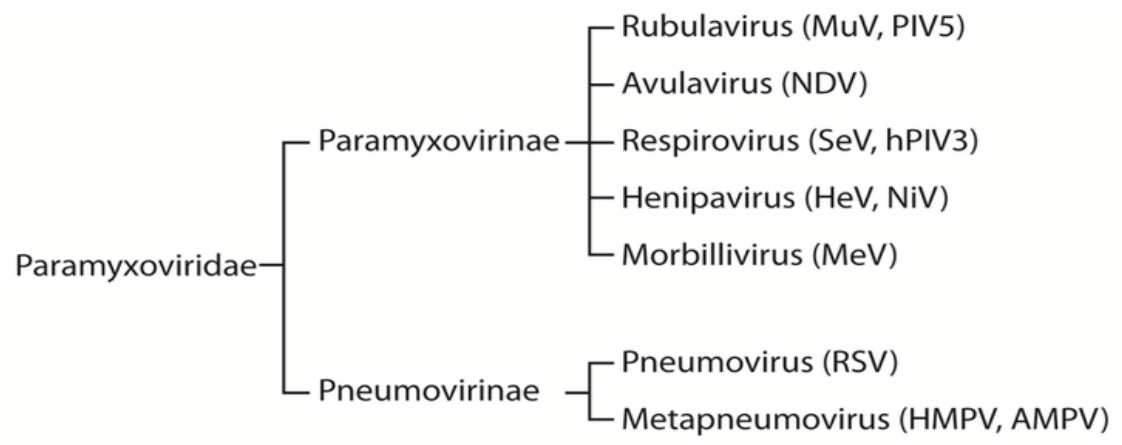

B.

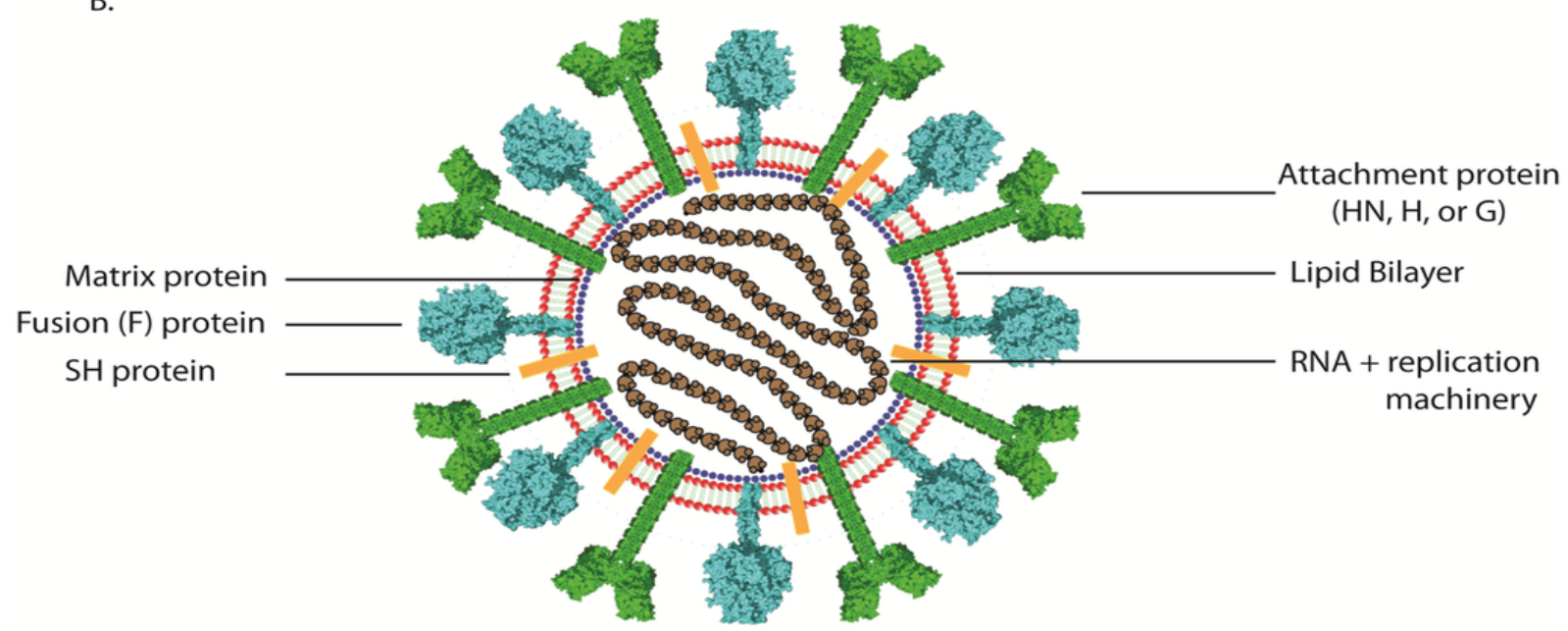

Figure 1: (A) Classification of representative members of the paramyxovirus family, the genus of ND Avulavirus. (B) Schematic of a paramyxovirus. Genomic RNA is wrapped by nucleocapsid core proteins (brown), which are connected to the viral envelope (red) by the matrix protein (blue). The attachment (green), small hydrophobic (present only in certain paramyxoviruses, orange), and fusion proteins (cyan) are depicted at the virus surface [34].

virus and serological diagnostics, such as HI Test, ELISA and molecular diagnostic tests like real time PCR confirmed the presence of velogenic Newcastle Disease Virus [11]. The economic importance of Newcastle disease may affect on the meat quality of poultry. In developing countries, the broiler meat is the cheapest source of animal protein. Availability of egg is increasing at rate of round about $4 \%$ annually [12] White meat's essential nutrients are same as red meat, but white meat has the advantage of containing less cholesterol and saturated fat. In most developing countries, meat is a very important protein sources in diet of people because it is affordability and has high quality protein [13]. In developing countries; the broiler meat is the cheapest source of animal protein. The objective of this review is to understand the Newcastle disease causative agent, pathogenicity, clinical sign and how to prevent and control the Newcastle disease, which concerned with the currently published or reported research. Recently, the disease which decreases the development of poultry production for industry is the infectious diseases, among infection disease Newcastle is the one which causes economical lose of poultry and its product.

\section{Literature Review}

\section{General description of poultry Newcastle disease}

Newcastle disease is a contagious viral disease of birds and considered one of the most important poultry diseases worldwide. The disease can vary from mild to severe. A highly contagious and severe form of the disease, called exotic Newcastle disease (END), is so deadly that many birds die suddenly without showing any signs of disease [14].

\section{Etiology}

Newcastle disease is caused by avian paramyxovirus serotype 1 [APMV-1] viruses, which, with viruses of the other eight APMV serotypes [APMV-2 to APMV-9], have been placed in the genus Avulavirus, sub-family Paramyxovirinae, family Paramyxoviridae, in the current taxonomy $[15,16]$. Newcastle disease belongs to order Mononegavirales, family Paramyxoviridae, sub family Paramyxovirinae and genus Avulavirus which are negative sense, single stranded and non-segmented RNA genomes [17]. All the avian paramyxoviruses APMVs are part of genus Avulavirus. Virions are roughly spherical;150 $\mathrm{nm}$ or more in diameter and filamentous [18]. The genome is about 15.2 $\mathrm{kb}$ in length $[19,20]$ that codes for six structural and two non-structural proteins [10]. Rule of six should be followed by genome because it should be of poly hexametric length to replicate rapidly. It encodes for six proteins in 3' to 5' direction; these are Nucleoprotein (NP), Large RNA polymerase (L), Fusion (F), Hemag-glutinin Neuraminidase $(\mathrm{HN})$, Matrix $(\mathrm{M})$ and phosphor protein $(\mathrm{P})[21,22]$. The proteins $\mathrm{W}$ and $\mathrm{V}$ are additionally created within the $\mathrm{P}$ gene during transcription of mRNA at editing site by insertion of guanines $[22,23]$. In virus particles, $\mathrm{NP}$ is the most abundant protein which provides the NDV score helical 
nucleocapsid structure. NP is the main regulator in replication of viral genome [25]. The genomic RNA is associated with NP, P and L proteins to form RNP complex, which serve as template for RNA synthesis [24]. $\mathrm{NP}$ is found to be highly immunogenic, as it induces antibody responses in chickens [26].

\section{Molecular basis for pathogenicity}

During the replication of NDV, the functionally important fusion protein is produced as a precursor glycoprotein, F0, which has to be cleaved to F1 and F2 for the progeny virus particles to be infectious [27]. This post translation cleavage is mediated by host cell proteases [28]. If cleavage fails to take place, noninfectious virus particles are produced. Trypsin can cleave F0 for all NDV strains, and in vitro treatment of non-infectious virus will restore infectivity [29]. The importance of F0 cleavage was easily demonstrated, because viruses normally unable to replicate or produce plaques in cell culture systems were able to do both if trypsin was added to the agar overlay or culture fluid. Although all viruses could replicate and produce infectious progeny in the allantois cavity, the viruses pathogenic for chickens could replicate in a wide range of cell types in vitro with or without added trypsin, whereas strains of low virulence could replicate only when trypsin is added [30]. Thus, F0 molecules of virulent viruses can be cleaved by a host protease or proteases found in a wide range of cells and tissues, but F0 molecules in viruses of low virulence were restricted in their sensitivity to cleavage by specific host enzymes. Consequently, these viruses can grow only in certain host cell types. Early reports of the deduced amino acid sequences of the F0 precursor, obtained from nucleotide sequencing of the F gene fora number of NDV strains [31,32], enabled comparison of viruses of low virulence to those that were velogenic or mesogenic. For all viruses, the amino acid at residue 116 , the $\mathrm{C}$ terminus of the $\mathrm{F} 2$ protein at the site of cleavage, was arginine. The viruses of low virulence all had leucine at residue 117, the $\mathrm{N}$-terminus of the $\mathrm{F} 1$ protein, and another basic amino acid at residue 113. In contrast, all velogenic or mesogenic viruses had phenylalanine at residue 117 and, with one exception, basic amino acids at residues 115 and 112 in addition to those at 113 and 116 . The exception was the pigeon variant PMV-1 virus, which was identical to the virulent viruses but lacked a basic amino acid at position 112 .

The strain of Newcastle pathogenicity: The strain of Newcastle pathogenicity can be classified into five pathotype:- Asymptomatic enteric strain a form that has sub-clinical enteric infection without clear symptoms; Lentogenic strain which virus present with the mild respiratory infections; Mesogenic stain which virus presents with rare nervous and respiratory signs while mortality rate is related with the age of susceptible birds (young birds are more susceptible as compare to adults); Viscerotropic velogenic strain which virus cause haemorrhagic intestinal lesions and it is highly pathogenic; Neurotropic velogenic strain which virus cause high mortalities followed by respiratory and nervous signs [33].

Epidemiology of Newcastle disease: Virulent NDV strains are endemic in poultry in most of Asia, Africa, and some countries of North and South America [34]. Other countries, including the USA and Canada, are free of those strains in poultry and maintain that status with import restrictions and eradication by destroying infected poultry. Cormorants, pigeons, and imported psittacine species are more commonly infected with vNDV and have also been sources of vNDV infections of poultry. NDV strains of low virulence are prevalent in poultry and wild birds, especially waterfowl. Infection of domestic poultry with loNDV contributes to lower productivity [35]. ND virus is infective for almost all avian species, both domestic and wild. Chickens are higly susceptible to infection with Newcastle disease virus, including the pigeon variant of APMV-1. Considered to be the most susceptible of domestic poultry species. Newcastle disease virus is heat stable when compared with most of paramyxovirus. It remain infectious in bone marrow and muscle of slaughtered chicken at least six month at $-20^{\circ} \mathrm{C}$ and for up to four month in refregrator temperature and also infectious virus may survive for months at room temperature in eggs laid by infected hens and for over year at $4^{\circ} \mathrm{C}$ [36]. Higher prevalence of ND is during dry season than wet season. However, rare higher prevalence of ND is also seen during wet season that may be related to Ethiopian Holidays (Filseta, Enkutatesh etc) celebrated during wet season. Human activity and increased turnover in the chicken markets during dry season could leads to outbreaks of NCD that have been attributed to high prevalence during dry season [37,38]. As studies reported on Newcastle disease that indicated high significant difference in NCD prevalence between local and cross breeds of chickens. Highest prevalence's are recorded in cross breeds of chickens than local breed [39]. The low altitudes do have higher prevalence than the mid and high [38-40]. Mortality may be very high, often reaching 50 to $100 \%$. The prevalence of NCD varies among years in Ethiopia.

\section{Transmission}

The transmission of NDV occurs through respiratory aerosols, exposure to fecal and other excretions from infected birds, through newly introduced birds, selling and giving away sick birds and contacts with contaminated feed, water, equipment and clothing. The usual 5 source of virus is an infected chicken, and spread is usually attributed to the movement of chickens through chicken markets and traders [41]. Newcastle disease is very contagious and is easily spread from one bird to another. The infection is usually transmitted by direct contact with sick birds or unaffected birds carrying the virus. Even vaccinated birds that are clinically healthy can excrete virulent virus after they have been exposed. Virus can also be transmitted indirectly by people, other animals, equipment, vehicles, contaminated poultry products, feed and water [42].

The infection takes place by inhalation or ingestion of the virus or by contact with mucous membranes, specially the conjunctiva. Infected birds shed virus in aerosol, respiratory discharge and faeces. Infected birds start to excrete virus during the incubations period and continue to excrete virus for a varying but limited time during convalescence [42].

During the course of infection of most birds with NDV, large amounts of virus are excreted in the feces. Ingestion of feces results in infection; this is likely to be the main method of bird-to bird spread for avirulent enteric NDV and the pigeon variant virus, neither of which normally produces respiratory signs in infected birds [43]. Vertical transmission (i.e., passing of virus from parent toprogeny via the embryo) remains controversial. The true significance of such transmission in epizootics of ND is not clear. Experimental assessment using virulent viruses is usually hampered by cessation of egg laying in infected birds. Infected embryos have been reported during naturally occurring infections of laying hens with virulent virus [44], but this generally results in the death of the infected embryo during incubation.

Cracked or broken infected eggs may serve as a source of virus for newly hatched chicks, as may virus-laden feces contaminating the outside of eggs. Virus may also penetrate the shell after laying [45], further complicating the assessment of true vertical or transovarian transmission. Infected chicks may be hatched from eggs infected with vaccinal or other lentogenic viruses that do not necessarily cause death 
of the embryo [46].

\section{Pathogenicity}

The virulence of NDV strains varies greatly with the host. Chickens are highly susceptible, but ducks may be infected and show few or no clinical signs, even with strains lethal for chickens [47]. In chickens, the pathogenicity of ND is determined chiefly by the strain of virus, although dose, route of administration, age of the chicken, and environmental conditions all have an effect. In general, the younger the chicken, the more acute the disease. With virulent viruses in the field, young chickens may experience sudden deaths without major clinical signs; however, in older birds the disease may be more protracted and with characteristic clinical signs. Breed or genetic stock does not appear to have a significant effect on the susceptibility of chickens to the disease [48].

\section{Clinical Sign}

The clinical signs in birds infected with ND virus vary greatly from very high morbidity and mortality to asymptomatic carriers. The severity of an infection is dependent on factors like the virulence and tropism of the virus, host species, age of host, immune status, other diseases and environmental conditions [49]. Symptoms from the respiratory tract are gasping, coughing, sneezing and rales. Signs from the nervous system include tremors, paralyzed wings and legs, twisted necks, circling, clonic spasms and sometimes complete paralysis. Other general symptoms that can be seen are greenish diarrhoea, depression and inappetence, partial or complete drop in egg production and an increased production of deformed eggs [49]. Clinical sign and course of disease can be grouped into four different pathotypes based on the strains of Newcastle disease virus [50]. These all four pathotypes are listed as follow:

Viscerotropic velogenic: That can be seen are obvious depression, inappetence, substantial drop in egg production, increased respiration, a profuse greenish-yellow diarrhoea that rapidly leads to dehydration and collapse, swollen heads and cyanotic combs. Mortality can be up to $90 \%$ and infected birds usually die within one or two days. Birds that survive the initial phase often develop nervous signs. Sometimes birds desperately without previous clinical signs.

Neuroptopic velogenic: Acute signs from the respiratory tract and nervous system dominate. Sudden depression, inappetence and drop in egg production are seen together with coughing and other signs from the respiratory tract, followed by nervous signs within a few days. Mortality is usually around $10-20 \%$ for adult birds but can be higher for young birds.

Mesogenic: Coughing and other signs from the respiratory tracts dominate. Other symptoms are depression, loss of weight and decreased egg production for up to three weeks. Signs from the nervous system can develop late in the disease. Mortality is around $10 \%$.

Lentogenic: Are often subclinical but mild respiratory signs and a small drop in egg production can be seen. No nervous signs and mortality is usually negligible.

\section{Pathology}

Gross lesions: As with clinical signs, the gross lesions and the organs affected in birds infected with NDV are dependent on the strain and pathotype of the infecting virus, in addition to the host and all the other factors that may affect the severity of the disease. No pathognomonic lesions are associated with any form of the disease. Gross lesions may also be absent. Nevertheless, the presence of hemorrhagic lesions in the intestine of infected chickens has been used to distinguish VVND viruses from NVND viruses [51]. These lesions are often particularly prominent in the mucosa of the proventriculus, ceca, and small and large intestine. They are markedly hemorrhagic and appear to result from necrosis of the intestinal wall or lymphoid tissues such as cecal tonsils and Peyer's patches. Generally, gross lesions are not observed in the central nervous system of birds infected with NDV, regardless of the pathotype [52]. Gross pathologic changes are not always present in the respiratory tract, but when observed they consist predominantly of mucosal hemorrhage and marked congestion of the trachea [53]. Air sacculitis may be present even after infection with relatively mild strains and thickening of the air sacs with catarrhal or caseous exudates is often observed in association with secondary bacterial infections [44].

\section{Diagnosis}

Clinical diagnosis based on history, signs and lesions may establish a strong index of suspicion but the laboratory confirmation must be done. Hemagglutination and hemagglutination inhibition test, virus neutralization test, Enzyme linked immune-sorbent assay, plaque neutralization test and reverse-transcriptase polymerase chain reaction (RT-PCR) can be used for confirmation of the ND virus [54]. Now RT-PCR is the most exclusively used method to detect AIVs and NDVs $[9,55,56]$. RT-PCR assay is more sensitive, specific and less labor intensives as compare to other conventional methods used for lab diagnoses such as virus isolation, Immuno-Fluorescence Staining, Neuraminidase Inhibition and ELISA $[57,58]$. Using modern technologies, new diagnostic techniques are being developed for identification and differentiation of NDV strains [59]. Other molecular diagnostic tests like real time PCR and nucleotide sequence analysis are also important in viral disease diagnosis $[58,60]$.

\section{Isolation and identification of causative agent}

Direct detection of viral antigens: Immuno histologic techniques offer a rapid method for the specific demonstration of the presence of virus or viral antigens in organs or tissues. Immunofluorescence techniques for thin sections of trachea [61], or impression smears [62] and an immunoperoxidase technique for thin sections $[63,64]$ have been reported and used in NDV infections.

Virus isolation of NDV: Although molecular techniques, especially those developed to employ RT-PCR directly on samples from affected birds [65], mean that a positive diagnosis at least can be obtained rapidly without virus isolation, it is still important that, for primary outbreaks especially, the virus is isolated for proper characterization and future work.

Culture system: Virulent ND viruses can be propagated in many cell culture systems, and viruses of low virulence can be induced to replicate in some of them. It is possible to use primary cell cultures or even cell lines for routine isolation of NDV. The embryonated chicken egg, however, represents an extremely sensitive and convenient vehicle for the propagation of NDV and is used almost universally in diagnosis. Embryonated chicken eggs should be obtained from a specific pathogen free (SPF) flock and incubated for $9-10$ days at $37^{\circ} \mathrm{C}$ before use. If SPF eggs cannot be obtained, eggs from a flock free of NDV antibodies should be used. NDV strains in eggs containing yolk antibodies can be propagated, but the virus titer is usually greatly reduced, and such eggs should be avoided for diagnostic use.

Serologic tests for Newcastle disease virus antibodies: Antibodies to NDV may be detected in poultry sera by a variety of tests including 
single radial immune diffusion [66], single radial hemolysis [67], agar gel precipitin [68], $\mathrm{VN}$ in chick embryos [69], and plaque neutralization [44]. Sera from other species (including turkeys) may cause low-titer, nonspecific agglutination of chicken RBCs, complicating the test. Such agglutination may be removed by adsorption with chicken RBCs before testing. Although the HA and HI tests are not greatly affected by minor changes in the methodology [70].

Differential diagnosis of Newcastle disease: Differential diagnosis is the process of differentiating Newcastle disease with other disease which share similar signs or symptoms. The disease which have similar clinical sign with Newcastle disease are as the follow: Fowl cholera, Highly pathogenic avian influenza, Laryngotracheitis, Fowl pox (diphtheritic form), Psittacosis (psittacine birds), Mycoplasmosis, Infectious bronchitis, Aspergillosis, Also management errors such as deprivation of water, lack of or nutritionally deficient feed and poor ventilation. In pet birds:- Pacheco's parrot disease (psittacine birds), salmonellosis, adenovirus, and other Paramyxoviruses, In cormorants and other wild waterfowl: botulism, fowl cholera and conformational abnormalities [71].

\section{Prevention and Control}

The general approaches to the control of Newcastle disease are hygiene and vaccination, this is always important, especially in the control of NCD in semi-intensive systems where birds are confined within a fenced yard or house. Hygiene includes measures such as cleaning, disinfection, limiting access to wild birds, and personal hygiene of the farm staff. Vaccination in combination with appropriate hygiene measures, this remains the most effective way of controlling NCD [72]. Vaccination against vND would result in immunity against infection and replication of the virus. Realistically, ND vaccination usually protects the bird from the more serious consequences of disease, but virus replication and shedding may still occur [73,74].

NCD vaccines are available in either "live" or "dead" forms: Live vaccines are fragile and have very precise rules for use, requiring a cold chain up to the point of application to the bird. Their effectiveness is reduced if there are residual antibodies in the chickens. The immune response increases as the pathogenicity of the live vaccine increases [75]. Therefore, to obtain the desired level of protection without serious reaction, vaccination programs are needed that involve sequential use of progressively more virulent viruses or live virus followed by inactivated vaccine. Killed vaccines give good immunity but require priming with a live vaccine for best results, unless a natural infection has already served this purpose. In Ethiopia, vaccination has been reported as the only safeguard against endemic NCD. However, vaccines currently in use are mainly of benefit to commercial poultry producers whose chickens are kept in large, single age, confined flocks. Manufacturers produce heat labile NCD vaccines in multidose vials, often containing 1,000 or 2,500 doses, which must be kept cold (within 19a 'cold chain') from manufacture until administration to the chickens. In contrast, village chickens are raised in small, multi-age, free-range flocks and large multi-dose vials of vaccine are inappropriate. The cold chain is difficult to maintain under village conditions and purchase of commercial vaccines is a drain on foreign exchange [76].

Vaccines are being used to control and prevent ND. Currently, many inactivated and live ND vaccines are available around the world $[77,78]$. Chickens and turkeys are immunized against New-castle disease. Live virus vaccines are administered by variety of routes and schedules from hatching till grow-out [79]. Killed virus oil emulsion vaccines are administered parentally prior to the onset of egg production.
Although proper vaccination protects the birds from clinical disease but it does not prevent virus replication and shedding, which results in a source of infection [80]. In developing countries, there is wide use of vaccines on commercial flocks [81]. Anti NDV antibody titers of flocks are continuously monitored and flocks are revaccinated to maintain the protective antibody titers. The breeders and layers are vaccinated against NDV and oil based vaccines are being used prior to onset of egg production for long term immunity $[82,83]$. Anti NDV antibody titers of breeder flock is also important to maintain the anti NDV maternal antibody titers of pro-geny. These maternal antibodies protect chicks from the disease during the first week of life. In spite of extensive vaccination, outbreaks are continuously occurring [60]. To overcome this problem poultry producers are using different combinations of live and killed vaccines in a flock. Good biosecurity measures are essential to prevent Newcastle disease in poultry flocks. Commercial flocks should not have any contact with domesticated poultry or wild birds or any pet birds. Workers should avoid contact with birds outside the farm. Biosecurity measures include bird-proof houses, feed and water supplies, minimizing travel on and off the facility, disinfecting vehicles and equipments that enter the farm. Pests such as insects and mice should also be controlled. If possible, employees should shower and change into dedicated clothing prior entry into the poultry farm.

\section{Public Health Important}

Humans are among the many species that can be infected by NDV in addition to avian species. NDV may cause conjunctivitis in humans, when a person has been exposed to large quantities of the virus [84]. Mostly, Laboratory workers and vaccinators are affected. The use of personnel protective equipment and biological safety cabinet has reduced the exposure of laboratory workers. Infection is rarely seen in the workers of a farm; moreover, persons handling or consuming poultry products do not appear to be at risk [85]. The conjunctivitis usually resolves rapidly, but the virus will be shed in the ocular discharges from 4 to 7 days. In some cases, mild, self-limiting influenza like disease with fever and headache has also been reported in humans $[83,84]$. There is no evidence found to support human to human transmission but the potential for human to bird transmission exists [84].

\section{References}

1. Pemin A, Pedersen G, Riise JC (2001) Poultry as a tool for poverty alleviation: Opportunities and problems related to poultry production at village level. In ACIAR proceedings, pp: 143-147.

2. FAO (2012) Faostat. Production. Live animals

3. Conan A, Goutard FL, Sorn S, Vong S (2012) Biosecurity measures for backyard poultry in developing countries: a systematic review. BMC Vet Res 8: 240 .

4. Nelson CB, Pomeroy BS, Schrall K, Park WE, Lindeman RJ (1952) An outbreak of conjunctivitis due to Newcastle disease virus (NDV) occurring in poultry workers. Am J Public Health Nations Health 42: 672-678.

5. Ashraf A, Shah MS (2014) Newcastle Disease: Present status and future challenges for developing countries. African J Microbiol Res 8: 411-416.

6. Naveen KA, Singh SD, Kataria JM, Barathidasan R, Dhama K (2013) Detection and differentiation of pigeon paramyxovirus serotype-1(PPMV-1) isolates by RT-PCR and restriction enzyme analysis. Trop Anim Health Prod 45: 12311236.

7. Maqbool A (2002) Marketing of commercial poultry, poultry meat and eggs in Faisalabad City. MSc Thesis, University of Agriculture Faisalabad, Pakistan.

8. Narayanan MS, Parthiban M, Sathiya P, Kumanan K (2010) Molecular detection of Newcastle disease virus using Flinders Molecular detection of Newcastle disease virus using Flinders Tehnology AssociatesPCR Tehnology Associates-PCR. J Veterinarski Arhiv 80: 51-60. 
Citation: Abdisa T, Tagesu T (2017) Review on Newcastle Disease of Poultry and its Public Health Importance. J Vet Sci Technol 8: 441. doi: 10.4172/2157-7579.1000441

Page 6 of 7

9. Haque MH, Hossain MT, Islam MT, Zinnah MA, Khan MSR et al. (2010) Isolation and Detection of Newcastle disease virus from field outbreaks in Broiler and Layer chickens by Reverse transcription Polymerase chain reaction. Bangl J Vet Med 8: 87-92.

10. Choi KS, Lee EK, Jeon WJ, Kwon JH (2010) Antigenic and immunogenic investigation of the virulence motif of the Newcastle disease virus fusion protein. J Vet Sci 11: 205-211.

11. Munir S, Hussain M, Farooq U, Zabid Ullah Jamal Q, Afreen M, et al. (2012) Quantification of antibodies against poultry haemagglutinating viruses by haemagglutination inhibition test in Lahore. Afr J Microbiol Res 6: 4614-4619.

12. Numan M, Zahoor MA, Khan HA, Siddique M (2005) Seroligical statuso Newcastle disease in broilers and layers in Faisalabad and surrounding districts. Pakistan Vet J 25: 55-58.

13. Thomazelli LM, Araujo JD, Ferreira CS, Hurtado R, Oliveira DB, et al. (2012) Molecular Surveillance of the Newcastle Disease Virus in Domestic and Wild Birds on the North-Eastern Coast and Amazon Biome of Brazil. Brazilian J Poult Sci 14: 01-07.

14. USDA- APHIS-VS (2008) Website.

15. Lamb RA, Collins D, Kolakofsky JA, Melero Y, Nagai MBA, et al. (2000) Family Paramyxoviridae. In: van Regenmortel MHV (ed.), Virus Taxonomy, Seventh Report of the International Committee on Taxonomy of Viruses. Academic Press: New York, USA, pp: 549-561.

16. Mayo MA (2002) A summary of the changes recently approved by ICTV. Arch Virol 147: 1655-1656.

17. Cattoli G, Susta L, Terregino C, Brown C (2011) Newcastle disease: are view of field recognition and current methods of laboratory detection. J Vet Diagn Invest 23: 637-656.

18. Catroxo MHB, Martins AMCRPF, Petrella S, Curi NA, Melo NA (2011) Research of viral agent in free-living pigeon feces (Columba livia) in the City of Sao Paulo, SP, Brazil, for transmission electron microscopy. Int J Morphol 29: 628-635.

19. Cao Y, Gu M, Zhang X, Liu W, Liu X (2013) Complete Genome Sequences of Two Newcastle Disease Virus Strains of Genotype VIII. Genome Announc 1: 01.

20. Zhang Y, Zhang S, Wang X, Zhang G (2012) Complete genome sequence of a sub genotype viid Newcastle disease virus circulating predominantly in chickens in China. J Virol 86: 13849-13850

21. Al-Habeeb MA, Mohamed MHA, Sharawi S (2013) Detection and characterization of Newcastle disease virus in clinical samples using real time RT-PCR and melting curve analysis based on matrix and fusion genes amplification. Vet World 6: 239-243.

22. Linde AM, Munir M, Zohari S, Stahl K, Baule C, et al. (2011) Complete genome characterization of a Newcastle disease virus isolated during an outbreak in Sweden in 1997. Virus Genes 41: 165-173.

23. Qiu X, Sun Q, Wu S, Dong L, Hu S, et al. (2011) Entire genome sequence analysis of genotype IX Newcastle disease viruses reveals their early-genotype phylogenetic position and recent-genotype genome size. Virol J 8: 01-11.

24. Kho CL, Tan WS, Tey BT, Yusoff K (2003) Newcastle disease virus nucleocapsid protein: self-assembly and length-determination domains. J Gen Virol 84: 2163-2168.

25. Kho CL, Tan WS, Tey BT, Yusoff K (2004) Regions on nucleocapsid protein of Newcastle disease virus that interact with its phosphoprotein. Arch Virol 149 $997-1005$

26. Ahmad-Raus R, Ali AM, Tan WS, Salleh HM, Eshaghib M, et al. (2009) Localization of the antigenic sites of Newcastle disease virus nucleocapsid using a panel of monoclonal antibodies. J ResVet Sci 86: 174-182.

27. Radhavan VS, Kumanan K, Thirumurugan G, Nachimuthu K (1998) Comparison of various diagnostic methods in characterizing Newcastle disease virus isolates from Desi chickens. Trop Anim Health Prod 30: 287-293.

28. Nagai Y, Klenk HD, Rott R (1976) Proteolytic cleavage of the viral glycoproteins and its significance for the virulence of Newcastle disease virus. Virology 72 494-508.

29. Nagai Y, Ogura H, Klenk HD (1976) Studies on the assemblyof the envelope of Newcastle disease virus. Virol 69: 523-538.

30. Rott R 1979. Molecular basis of infectivity and pathogenicity of myxoviruses. Arch Virol 59: 285-298.
31. Collins MS, Bashiruddin JB, Alexander DJ (1993) Deduced amino acid sequences at the fusion protein cleavage site of Newcastle disease viruse showing variation in antigenicity and pathogenicity. Arch Virol 128: 363-370.

32. Toyoda T, Sakaguchi T, Imai K, Mendoza IN, Gotoh B, et al. (1987) Structural comparison of the cleavage-activation site of the fusion glycoprotein between virulent and avirulent strains of Newcastle disease virus. Virol 158: 242-247.

33. OIE (2012) Newcastle disease. Manual of Diagnostic Tests and Vaccines for Terrestrial Animals. Chapter 2.3.14.

34. Chang A, Dutch RE (2012) Paramyxovirus fusion and entry: multiple paths to a common end. Viruses 4: 613-636.

35. Merck (1995) Newcastle disease. Merck \& Co. Inc., Kenilworth, NJ, USA Available from: http://www.merckvetmanual.com/poultry/newcastle-diseaseand-other-paramyxovirus-infections/newcastle-disease-in-poultry

36. Fenner FF, Bachmann PA, Gibbs EPJ, Murphy FA, Studdert MJ, et al. (1987) Paramyxoviridae. In: Veterinary Virology, Academic Press, Orlando, Florida, 493.

37. Nega M, Moges F, Mazengia H, Zeleke G, Tamir S (2012) Evaluation of 12 thermostable Newcastle disease vaccine on local chickens in selected districts of Western Amhara. J Anim Feed Res 2: 244-248.

38. Zeleke A, Sori T, Gelaye E, Ayelet G (2005) Newcastle Disease in Village Chickens in the Southern and Rift Valley Districts in Ethiopia. Int J Poultry Sci 4: 507-510.

39. Belayheh G, Moses NK, Melese B, Fufa D (2014) Seroprevalence of Newcastle Disease Virus Antibodies in Village Chickens in Kersana-kondalaity District, Ethiopia. Global Veterinaria 12: 426-430.

40. Serkalem T, Hagos A, Zeleke A (2005) Seroprevalence Study of Newcastle Disease in Local Chickens in Central Ethiopia. Int J Appl Res Vet Med 3: 1.

41. Desalegn JM (2015) Epidemiology of Village Chicken Diseases: A Longitudinal Study on The Magnitude and Determinants of Morbidity and Mortality- The Case of Newcastle And Infectious Bursal Disease. Addis Ababa University College of Veterinary Medicine and Agriculture, Department of Clinical Study.

42. Caupa I, Alexander DJ (2009) Avian Influenza and Newcastle Disease a Field and Laboratory Manual. Milan: Springer-Verlag.

43. Alexander DJ, Parsons G, Marshall R (1984) Infection off owls with Newcastle disease virus by food contaminated with pigeon feces. Vet Rec 115: 601-602.

44. Beard CW, Hanson RP (1984) Newcastle disease. In: Hofstad MS, Barnes HJ, Calnek BW, Reid WM, Yoder HW (eds.), Diseases of Poultry, 8th edn. lowa State University Press: Ames, IA, USA, pp: 452-470.

45. Williams JE, Dillard LH (1968) Penetration patterns of Mycoplasma gallisepticum and Newcastle disease virus through the outer structures of chicken eggs. Avian Dis 12: 650-657.

46. Coman I (1963) Possibility of the elimination of strain F virus of Asplin (1949) in the eggs of inoculated hens. Lucr Inst Past Igiena Anim Buc 12: 337-344.

47. Higgins DA (1971) Nine disease outbreaks associated with myxoviruses among ducks in Hong Kong. Trop Anim Health Prod 3: 232-240.

48. Cole RK, Hutt FB (1961) Genetic differences in resistance to Newcastle disease. Avian Dis 5: 205-214.

49. Kahn CM (2005) The Merck Veterinary Manual. 9th edn. Philadelphia: National Publishing Inc.

50. Alexander DJ, Bell JG, Alders RG (2004) A Technology Review: Newcastle Disease. With Special Emphasis on its Effect on Village Chickens. FAO Animal Production and health Paper (FAO)

51. Hanson RP (1980) Newcastle disease. In: Hitchner SB, Domermuth $\mathrm{CH}$ Purchase HG, Williams JE (eds.), Isolation and Identification of Avian Pathogens. American Association of Avian Pathologists: Kennett Square, PA USA, pp: 63a-66a

52. McFerran JB, McCracken RM (1988) Newcastle disease. In: Alexander DJ (ed.), Newcastle Disease. Kluwer Academic Publishers, Boston, MA, USA, pp: 161-183.

53. Alexander DJ, Allan WH (1974) Newcastle disease virus pathotypes. Avian Pathol 3: 269-278.

54. Chaka H, Goutard F, Gil P, Abolnik C, Almeida R, et al. (2013) Serological and molecular investigation of Newcastle disease in household chicken flocks and associated markets in Eastern Shewa zone, Ethiopia. Trop Anim Health Prod 
Citation: Abdisa T, Tagesu T (2017) Review on Newcastle Disease of Poultry and its Public Health Importance. J Vet Sci Technol 8: 441. doi: 10.4172/2157-7579.1000441

\section{5: $705-714$}

55. Liu H, Zhao Y, Zheng D, Lv Y, Zhang W, et al. (2011) Multiplex RT-PCR for rapid detection and differentiation of class I and class II Newcastle disease viruses. J Virol Methods 171: 149-155.

56. Wakamatsu N, King DJ, Seal BS, Brown CC (2007) Detection of Newcastle disease virus RNA by reverse transcription polymerase chain reaction using formalin fixed, paraffin-embedded tissue and comparison with immune histochemistry and in situ hybridization. J Vet Diagn Investigation 19: 396-400.

57. Tang Q, Wanga J, Bao J, Sun H, Sun Y, et al. (2012) A multiplex RT-PCR assay for detection and differentiation of avian $\mathrm{H} 3, \mathrm{H} 5$, and $\mathrm{H} 9$ subtype influenza viruses and Newcastle disease viruses. J Virol Methods 181: 164-169.

58. Shahzad M, Rizvi F, Khan A, Siddique M, Khan MZ, et al. (2011) Diagnosis of avain paramyxovirus type-1 infection in chicken by immunoflourescence technique. Int J Agric Biol 13: 266-270.

59. Rezaeianzadeh G, Dadras H, Safar A, Ali M, Nazemshirazi MH (2011) Serological and molecular study of Newcastle disease virus circulating in village chickens of Fars province, Iran. J Vet Med Anim Health 3: 105-111.

60. Shabbir MZ, Goraya MU, Abbas M, Yaqub T, Shabbir MA, et al. (2012) Complete Genome Sequencing of a Velogenic Viscerotropic Avian Paramyxovirus 1 Isolated from Pheasants (Pucrasia macrolopha) in Lahore, Pakistan. J Virol 86: $13828-13829$.

61. Hilbink F, Vertommen M, Van't Veer JTW (1982) The fluorescent antibody technique in the diagnosis of a number of poultry diseases: Manufacture of conjugates and use. Tijdschr Diergeneeskd 107: 167-173.

62. McNulty MS, Allan GM (1986) Application of immunofluorescence in veterinary viral diagnosis. In: McNulty MS, McFerran JB (eds.), Recent Advances in Virus Diagnosis. Martinus Nijhoff: Dordrecht, The Netherlands, pp: 15-26.

63. Hamid H, Campbell RSF, Lamihhane CM, Graydon R (1988) Indirect immunoperoxidase staining for Newcastle disease virus (NDV). Proc 2nd Asian/Pacific Poult Health Conf. Australitan Veterinary Poultry Association: Sydney, Australia, pp: 425-427.

64. Lockaby SB, Hoerr FJ, Ellis AC, Yu MS (1993) Immunohistochemical detection of Newcastle disease virus in chickens. Avian Dis 37: 433-437.

65. Gohm DS, Thur B, Hofmann MA (2000) Detection of Newcastle disease virus in organs and feces of experimentally infected chickens using RT-PCR. Avian Pathol 29: 143-152.

66. Chu HP, Snell G, Alexander DX, Schild GC (1982) A single radial immunodiffusion test for antibodies to Newcastle disease virus. Avian Pathol 11: 227-234.

67. Hari Babu Y (1986) The use of a single radial haemolysis technique for the measurement of antibodies to Newcastle disease virus. Indian Vet J 63: 982984.

68. Gelb J, Cianci CG (1987) Detergent-treated Newcastle disease virus as an agar gel precipitin test antigen. Poult Sci 66: 845-853.

69. Beard CW (1980) Serologic Procedures. In: Hitchner SB, Domermuth $\mathrm{CH}$, Purchase $\mathrm{HG}$, Williams JE (eds.), Isolation and Identification of Avian Pathogens. American Association of Avian Pathologists: Kennett Square, PA, USA, pp: 129-135.
70. Brugh M, Beard CW, Wilkes WJ (1978) The influence of test conditions on Newcastle disease hemagglutination-inhibition titers. Avian Dis 22: 320-328.

71. OIE (2013) Newcastle disease. Epidemiology Diagnosis Prevention and Control.

72. Moerad B (1987) Indonesia: Disease Control. In: Copland JW (ed.), Newcastle Disease in Poultry: A New Food Pellet Vaccine. ACIAR Monograph No. 5: 7376.

73. Alexander DJ, Manvell RJ, Banks J, Collins MS, Parsons G, et al. (1999) Experimental assessment of the pathogenicity of the Newcastle disease viruses from outbreaks in Great Britain in 1997 for chickens and turkeys and the protection afforded by vaccination. Avian Pathol 28: 501-512.

74. Guittet M, Le Coq H, Morin M, Jestin V, Bennejean G (1993) Distribution of Newcastle disease virus after challenge in tissues of vaccinated broilers. In: Proceedings of the Xth World Veterinary Poultry Association Congress, Sydney, p: 179.

75. Reeve P, Alexander DJ, Allan WH (1974) Derivation of an isolate of low virulence from the Essex '70 strain of Newcastle disease virus. Vet Rec 94: 38-41.

76. USMAN M (2002) Effects of vaccination of chickens against Newcastle disease with thermostable V4 and Lasota vaccines using different grains and their brans as vehicle.

77. Shim JB, So HH, Won $\mathrm{HH}$, Mo I (2011) Characterization of avian paramyxovirus type 1 from migratory wild birds in chickens. J Avian Pathol 40: 565-572.

78. Xiao S, Paldurai A, Nayak B, Mirande A, Collins PL, et al. (2013) Complete genome sequence of a highly virulent Newcastle disease virus currently circulating in Mexico. Genome Announce 1: 01-02.

79. Cho S, Kwon H, Kim T, Kim JH, Yoo H, et al. (2008) Characterization of a Recombinant Newcastle Disease Virus Vaccine Strain. Clin Vaccine Immunol 15: $1572-1579$.

80. Chukwudi OE, Chukwuemeka ED, Mary U (2012) Newcastle disease virus shedding among healthy commercial chickens and its epidemiological importance. Pakistan Vet J 32: 354-356.

81. Munir M, Zohari S, Abbas M, Berg M (2012b) Sequencing and analysis of the complete genome of Newcastle disease virus isolated from a commercia poultry farm in 2010. Arch Virol 157: 765-768.

82. Nadeem Y, Chaudhary TM, Shah MS, Ashraf A (2004) Oil adjuvanted Newcastle disease vaccine production using local viral isolates. Proceedings of 24th Pakistan Congress of Zoology. pp: 51-56.

83. Alexander DJ (2000) Newcastle disease and other avian paramyxoviruses Rev Sci Tec. 19: 443-462.

84. Nolen RS (2003). Emergency declared: exotic Newcastle disease found in commercial poultry farms. J Am Vet Med Assoc 222: 411.

85. David E, Daniel JK (2003) Zoonosis update: Avian influenza and Newcastle disease. JAVMA 222: 1534-1540. 